\title{
Environmental Sustainable Credit Management by Internal Auditor (Case Study in PT. BPR Prismaberlian Danarta Branch of Kranji)
}

\author{
Endah Prawesti Ningrum ${ }^{1} \&$ Ida Farida $^{2}$ \\ \{endah.prawesti.ningrum81@gmail.com ${ }^{1}$,idafaridah90@yahoo.com $\left.{ }^{2}\right\}$ \\ ${ }^{1}$ Accounting Department, Universitas Bhayangkara, J1. Raya Perjuangan No.81,Marga Mulya, \\ Bekasi Utara, Kota Bekasi,Jawa Barat 17143, Indonesia \\ ${ }^{2}$ Accounting Department, Politeknik Harapan Bersama, Jalan Mataram No.9, Kota Tegal Jawa \\ Tengah 52142, Indonesia
}

\begin{abstract}
In this study internal audit which is supervision in the bank, which can help in the process of achieving the objectives. This objective is to assist management in the banking internal operational control process that is very vulnerable to certain risks and to obtain an overview of the effectiveness of internal audits and credit provision. Internal audit is very important and cannot be separated from internal control in providing credit. So that it has a purpose so that the procedure in granting credit can be achieved well. The method used is a qualitative method with descriptive analysis, where researchers analyze and compare with a number of existing theories. The purpose of this study was to determine the adequacy of the application of internal audit in the provision of credit. The results show that based on an analysis of the implementation of internal audit qualifications that support internal control is very effective and very adequate at $81 \%$ and $96 \%$ which have played an important role in internal audit. In terms of credit provision, both credit procedures and analysis of the 5C and 7P principles at PT. BPR PrismaBerlian Danarta Kranji branch that has been applied to this loan which shows 85 $\%$ has been running well and is very adequate.
\end{abstract}

Keywords: Internal Audit, Internal Control, Environmental Sustainable credit, and Management.

\section{Introduction}

The bank is a financial institution engaged in finance that collects community funds and channel to parties requiring. Banking institutions also play a role as Development Agents in national development, where banks channel funds to the public in the form of loans and in the form of deposits, in order to improve people's lives [1].

As is the case with PT. BPR Prisma Berlian Danarta, which has banking services provide various facilities such as credit, accept deposits of public money in the form of savings and deposits, obtain profits in the form of interest with the aim of liquidity and the Bank as a lender (creditor) performs its role based on a policy to always maintain the right balance to earn interest in the interest of liquidity and solvency .

The level of competition between banks and high credit risk causes the bank management to implement an adequate internal control where the control aims to protect company property by minimizing the possibility of fraud, waste, credit congestion, and increasing efficiency and 
effectiveness of performance. With adequate internal control, it is expected to guarantee that the credit granting process will be able to avoid mistakes and fraud that will occur [2].

What are the benefits of sustainable lending for both the borrower and lender over and above a usual bank loan? One of the primary drivers is that it demonstrates innovation and a commitment to adapting business models to a changing context.

In connection with the number of cases in bad credit caused by the inability of customers to fulfill their obligations, problems arise undesirable. To avoid the occurrence of irregularities in giving credit properly, the bank must develop a sustainable credit policy comprehensive and clear taking into account various kinds of factors and criteria determine the quality of the policy. To achieve the bank's goals to be effective and the bank does not have a problem, an adequate sustainable credit by internal audit is needed. Based on the description above, this research is aimed at: How to implement internal audit carried out at PT. Prisma Berlian Danarta Kranji branch for granting credit?

\section{Sustainable lending}

Businesses often seek funds from external sources to dedicate finance to new projects and invest in future growth. Bank loans, as a form of debt capital, provide one such way of doing so. The new sustainability loan concept links the interest rate of the bank loan, i.e. the cost of capital, to meeting pre-agreed sustainability performance targets. In other words, the better sustainability performance demonstrated by a company the lower interest rate it gets - thereby reducing debt financing costs.

Sustainability-linked loans are different from existing green loans and bonds, because they can be used for everyday corporate purposes - for green bonds and loans the proceeds are earmarked to only fund projects with positive environmental benefits [3]

Lending the assessment uses several principles, namely the $5 \mathrm{C}$ principle and the $7 \mathrm{P}$ principle [4]

\subsection{C principle.}

The principle of giving credit with this 5C concept includes: (1) Character (Personality). Character is the nature or character of a person. The nature or character of someone who will be given credit really must be trusted. In this case the company believes it is true that the prospective debtor has a good reputation, which means always keeping up promises and not involved in matters relating to crime, such as gamblers, drunks, or cheater. To be able to read the nature or character of the prospective debtor can be seen the essence of consumer background, both in the background

Work or personal nature such as the way of life or lifestyle adopted, circumstances family, hobbies and social life. (2) Capacity. Capacity is an analysis to determine the ability of consumers in pay credit. Finance companies must know for certain the ability of candidates debtor (customer) by analyzing their business from time to time. (3) Capital (Capital). To see whether capital usage is effective or not, can be seen from the financial statements (balance sheet and income statement) which presented by measuring such as in terms of liquidity and solvency, profitability and other sizes. (4) Collateral (collateral or collateral). Is a guarantee given by customers both physical and non-physical.

Guarantees should exceed the amount of credit given. Guaranteed validity must also be examined and its perfection, so that if a problem occurs, the guarantee that is deposited will be used as soon as possible. (5) Condition of Economic (economic condition). Condition of 
Economic, namely political and social situations and conditions, economy, culture that affects business customer later.

\subsection{P principle}

The principle of granting credit with the $7 \mathrm{P}$ concept includes:

1. Personality

Personality (personality) is the nature and behavior of customers who apply for credit in question, used as material for consideration of credit. This customer personality can be known by collecting information about heredity, occupation, education, and association. Assessing customers in terms of their personality or behavior everyday and past. Personality also includes the attitudes, emotions, behavior and actions of customers in dealing with a problem.

\section{Party}

Classify customers in certain classifications or groups based on their capital, loyalty and character.

3. Purpose (Purpose)

Purpose (purpose) is the purpose and use of credit by this customer will be the thing that determines whether the prospective debtor's request is approved or rejected.

\section{Prospect}

To assess a customer's business in the future, it is profitable and has prospects or vice versa. Prospect is the prospect of the company in the future, whether it will be profitable or harmful.

\section{Payment}

Payment (payment) is knowing how the credit repayment given this can be known if the credit analysis takes into account the smoothness of sales and customer income so that it can estimate its ability to repay the credit in accordance with the agreement.

\section{Profitability}

To analyze how a customer is able to make a profit. Profitability is measured from period to period whether it will remain the same or will increase.

\section{Protection}

It is intended to guard against unexpected matters, the bank needs to protect the credit provided by asking for collateral from the debtor or insurance from the insurance, both from the credit side and from the credit side.

There are alternatives in resolving problem loans, namely

1. Repayment

For repayment of credit, the debtor can submit a loan repayment application with the scheme:

- Payment by another party

- Take over by another company

- Self-completion by the concerned 


\section{Rescheduling (Rescheduling)}

Rescheduling is a change in credit terms that are limited to changes to the payment schedule or time period, including a good grace period which includes changes in the amount of installments or not.

\section{Reconditioning (Return Requirements)}

Reconditioning is a change in part or all of the credit terms that are not limited to changes to the payment schedule, time period and / or other requirements as long as it does not involve changes to the maximum credit balance.

\section{4. $\quad$ Restructuring}

Restructuring is a change in credit terms regarding:

- Adding bank funds

Convert all or part of interest arrears into new credit principal Conversion of all or part of credit into investment in a company.

\section{Submission of Bad Credit to BPUN / BPULN}

Bad loans before being submitted to BUPN / BUPLN by banks must be written off in advance from the loan account of the data base (computer) file of the branch office. For this reason the branch office can propose to the head office in the credit division in charge and then the credit division will forward the branch office proposal to the board of directors.

Submission of bad credit billing to BUPN / BUPLN can be done after fulfilling the following requirements:

$\square$ It has been attempted to collect credit as optimally but without success

$\square$ Does not meet the criteria for credit rescue in the form of Rescheduling, Reconditioning and Restructuring.

$\square$ All credit files are reviewed for their validity, binding guarantees have been implemented optimally

$\square$ Has fulfilled the procedures and procedures for submission to BUPLN / BUPN

Crediting procedures are distinguished between individual loans and legal entities, which can generally be explained as follows, [3]:

1. Submission of files

The submission of a credit proposal should include, among others:

a. Company background

b. Purpose and purpose

c. Credit size and time period

d. How to refund credit

e. Credit guarantee

Furthermore, this proposal is accompanied by the required documents such as:
a. Notary office
b. Sign of company list (TDP)
c. Taxpayer Identification Number (NPWP)
d. Readings and income statements for the last 3 years 
e. Proven self from company leaders

f. Photocopy of guarantee certificate

The assessment we can do temporarily is from the existing balance sheet and income statement using the following ratios:

a. Current Ratio

b. Inventory Turn Over

c.Sales To Receivable Ratio

d. Profit Margin Ratio

e. Return On Net Worth

f.Working Capital

\section{Investigation of loan files}

The aim is to find out whether the loan file submitted is complete according to the requirements and is correct. If according to the banking party is not complete or sufficient then the customer is asked to complete it immediately and if the customer is unable to complete the shortage until a certain time limit, then the credit application should be canceled.

\section{Interview I}

Is an inquiry to prospective borrowers by directly dealing with prospective borrowers.

4.On the Spot

Is an inspection activity to the field by reviewing various objects that will be used as a business or guarantee. Then the results are matched with the results of interview I.

\section{Interview II}

Is a file repair activity, if possible there are shortcomings when after being done on the spot in the field.

\section{Credit Decision}

The credit decision in this case is to determine whether the credit will be given or refused, if accepted, the administration is prepared.

Usually includes:

a. amount of money received time period

b. and the costs that must be paid

\section{Signing of other credit / agreement agreements}

This activity is a continuation of the credit decision, so before the credit is disbursed, the prospective customer first signs a credit agreement.

\section{Credit realization}

Awarded after signing the required documents by opening a checking account or savings at the bank concerned.

\section{Internal Audit}

IIA introduced the SPPIA Standards for the Professional Practice of Internal Auditing (Standard) which contains the following definitions: "Internal audit is an independent assessment function established in the company to examine and evaluate its activities as a service provided to the company"[5] 
The definition of internal audit is as follows:

"Internal audit is an examination carried out by the company, both on the company's financial statements and accounting records, as well as compliance with the predetermined top management policies and compliance with government regulations and provisions of the applicable professional ties."

Thus, the definition of internal audit is an independent assessment function formed by organizations that examine and assess organizational activities or as services to the organization.[5]

Internal audit has various functions including:

1. Supervision of all activities that are difficult to handle by top leaders.

2. Identification and minimization of risks.

3. Report Validation to the manager.

4. Support and assist management in technical fields.

5. Replacing the decision making process.

6. Analyze the future (not for what has happened).

7. Helping managers in managing the company.

\section{Internal control}

In general, Internal Control is a plan, method, procedure and policy designed by management to provide adequate guarantees for operational efficiency and effectiveness, financial reporting reliability, asset security, compliance / compliance with laws, policies and other regulations .

Internal control as a process carried out by the board of commissioners, management and other personnel of the entity which is designed to provide reasonable assurance about the achievement of the following three categories of objectives: (a) reliability of financial reporting, (b) effectiveness and operating efficiency, and (c) compliance with applicable laws and regulations [6].

An internal control can be said to be effective if the three categories of company objectives can be achieved, namely with the conditions:

a. Director and management get an understanding of the direction of achieving corporate goals, by, including achieving the goals or targets of the company, including the performance, profitability level, and the company's resource security,

b. The published financial statements are reliable and reliable, which includes segment and interim reports,

c. The procedures and regulations established by the company have been obeyed and obeyed accordingly [7].

The purpose of internal control is to ensure that company management:

a. The company's stated objectives will be achieved.

b. Financial reports produced by the company can be trusted.

c. Company activities are in line with applicable laws and regulations [7].

\section{Method}

This research method is a descriptive research with observation instrument method, and questionnaire in data collection. This research method uses descriptive analysis method, which aims to provide a clear picture of the bank. The data obtained will be analyzed then compared to the existing theoretical basis so that in conclusion a conclusion can be drawn [8]. 


\section{a. Sampling Method}

The population in this study was conducted for data collection techniques by distributing questionnaires. The population is employees who are in the credit department and internal supervisory units. The sampling technique used in distributing questionnaires is the Probability Sampling technique. This technique is a sampling technique that provides equal opportunities for each element (member) of the population selected as sample members [9] .With a sample sub technique that is Simple Random Sampling, it is said to be simple because the taking of sample members from the population is done randomly without regard to the strata that exist in the population [9].

\section{b. Data Analysis}

Data analysis techniques in qualitative research using descriptive statistics, are statistics used to analyze data by describing or describing data that has been collected as it is without intending to make generally accepted conclusions. The results data obtained, then carried out an analysis by the author to find out the implementation of internal audit is very adequate to the provision of credit, collected through an assessment of the results of the questionnaire using percentage calculations.

\section{Disbursement of Credit Facilities}

Before disbursement, customers are required to pay for the closing of the insurance policy, notary fees and administration fees. Disbursement cannot be done if the customer has not paid this fee [10].

Realization of financing disbursement is given after signing the required documents by opening a savings account at PT. BPR PrismaBerlian Danarta Kranji branch. Thus withdrawal of financing funds can be done through an account that has been opened. Disbursement or withdrawal of money from an account as a realization of financing provision can be taken in accordance with the financing objectives. Disbursement of financing funds depends on the Bank's agreement with the customer, usually done simultaneously or gradually.

This monitoring process is carried out to monitor how the customer's business, as well as collateral that is guaranteed by the customer. This process is very useful so that the bank can find out the possibility of bad credit or not. In providing credit there is also bad credit at PT. BPR PrismaBerlian Danarta. Caused by intentions on the part of the Bank or debtor pihhak and intentional factors, so that the debtor experiences difficulties in fulfilling his obligations [10].

Based on the results of research conducted, there are several causes of problem loans, namely:

a. Internal factor of the bank

$\checkmark$ In credit analysis is not appropriate

Less selective in choosing prospective borrowers

b. Factor of the debtor

The designer who is experiencing a disaster

There are weaknesses in business management carried out by the debtor, Debtor'sdishonesty in managing credit The debtor party has a termination of work relationship There is a bad faith from the debtor 
Table 4.2 . Credit Collectibility of PT. BPR PrismaBerlian Danarta Kranji branch(in thousands of rupiah)

\begin{tabular}{|l|l|l|l|l|l|}
\hline Year & $\begin{array}{l}\text { Distribution } \\
\text { credits } \\
(\mathrm{Rp})\end{array}$ & $\begin{array}{l}\text { Current } \\
(\mathrm{Rp})\end{array}$ & $\begin{array}{l}\text { Bad } \\
\text { Credits } \\
(\mathrm{Rp})\end{array}$ & $\begin{array}{l}\text { Bad } \\
\text { NPL } \\
\%\end{array}$ & information \\
\hline 2015 & 2.781 .831 & 2.730 .968 & 50.863 & 1,8 & - \\
\hline 2016 & 2.446 .478 & 2.418 .334 & 28.144 & 1,2 & down \\
\hline 2017 & 3.958 .172 & 3.921 .695 & 36.477 & 0,9 & down \\
\hline
\end{tabular}

The level of NPL obtained in the percentage was $1.8 \%$ and in 2016 the percentage obtained by PT. Prisma BPR Original Danarta is $1.2 \%$ and has a deep decline in that the resulting value is better than the previous year which was $0.9 \%$.

This means that the level of bad credit at PT. BPR Prisma in the original Danart has done a good performance and always maintains and monitors the loans provided by PT. BPR Prisma Original Danarta remains healthy and repayment of loan installments runs smoothly, because the level of NPL PT. PrismaBerlian BPR Danarta Kranji branch is healthy, which is under 5\% in accordance with Bank Indonesia regulation Number 17/11 / PBI / 2015 dated 25 June 2015. On credit, it will experience risk, and things cannot be avoided, at PT. BPR PrismaBerlian Danarta Kranji branch has several ways to resolve non-performing loans or bad loans faced. Steps taken by PT. BPR PrismaBerlian Danarta Kranji branch, namely:

\section{Handling Watch List}

It is an act of early monitoring of credit with current collectibility and special attention, with the aim of providing a level of debtor. .

\section{Coaching}

In the development of non-performing loans, an effort is made by the bank in order to fulfill the conditions and conditions by the debtor listed in the Credit Agreement including the collection effort.

\section{Rescue}

Represents efforts made by the Bank against debtors who experience congestion in their payment of obligations. His efforts include restructuring and other actions, namely the addition of credit limits and the acquisition of debtor / collateral assets.

\section{Confiscation of guarantees}

It is the last resort if the customer really has no etiquette, good or unable to pay all his debts. 


\section{Delete the book}

It is an administrative action taken by the Bank to delete the bad credit book from the balance sheet as much as the debtor's obligation without removing the Bank's claim of rights to the intended debtor. Delete this book is confidential to the debtor.

\section{Delete invoices}

Is a liability / debt bill permanently and will be completely eliminated. The obligation of the debtor is deemed paid off, for example the victims of natural disasters whose nature has been determined as a national disaster.

\section{Conclusion}

Based on the results of the analysis and discussion that have been carried out, it can be concluded that the implementation of internal audit at PT. BPR PrismaBerlian Danarta Kranji branch is very effective and adequate. This is supported by the achievement of indicators on internal audit qualifications that reach the target of $100 \%$ of the minimum target set at PT. BPR PrismaBerlian Danarta Kranji branch. From the results of the questionnaires distributed, it has also shown that $81 \%$ of internal audit qualifications are effective and very adequate. And on the internal control side it is also very effective and very adequate which shows $96 \%$ which has an important role in internal audit.

In terms of credit provision, both credit procedures and analysis of the $5 \mathrm{C}$ and $7 \mathrm{P}$ principles at PT. BPR PrismaBerlian Danarta Kranji branch that has been applied to this loan which shows $85 \%$ has been going well. Based on the conclusions that have been stated, the hypothesis which states that the implementation of internal audit of lending at PT.BPR PrismaBerlian Danarta, Kranji branch is effective and very adequate and there are SOPs for handling NPLs that support when problem loans are sufficient. Managerial Implications Based on the conclusions that have been raised, there are managerial implications proposed to PT. BPR PrismaBerlian Danarta Kranji branch from the results of this study are:

1) The internal auditor should maintain the quality and internal control in auditing at PT. BPR Prisma Berlian Danarta Kranji branch.

2) It is expected that the implementation of supervision and control of credit disbursement to customers is carried out actively and continuously, so that the provision of disbursed loans can be controlled and minimize the occurrence of problem loans (bad loans).

3) Increase supervision of the operationalization and performance of employees in carrying out their duties, especially in the crediting process, so that PT. BPR PrismaBerlian Danarta Kranji branch can be trusted more by customers.

\section{References}

[1] O. Weber, R. W. Scholz, and G. Michalik, "Incorporating sustainability criteria into credit risk management," Bus. Strateg. Environ., 2010.

[2] M. Jeucken and J. Bouma, "The changing environment of banks," Greener Manag. Int., 1999.

[3] L. Gambacorta and P. E. Mistrulli, "Does bank capital affect lending behavior?," J. Financ. Intermediation, 2004.

[4] H. Lange, A. Saunders, D. Thompson, and J. Anderson, Financial Institutions Management. 2007. 
[5] IIA, "The role of internal auditing in enterprise-wide risk management," Inst. Intern. Audit., 2009.

[6] F. H. Fadzil, H. Haron, and M. Jantan, "Internal auditing practices and internal control system," Manag. Audit. J., 2005.

[7] The Institute of Internal Auditors (IIA), "The three Lines of Defense in effective Risk Management and Control," 2013.

[8] S. Setijono, "Statistika Deskriptif," in Statistika untuk Ekonomi dan Keuangan Modern, 2016.

[9] Sugiyono, "Metode Penelitian Kuantitatif, Kualitatif dan Kombinasi (Mixed Methods)," Bandung Alf., 2016.

[10] J. Cohen, "Nominal scale agreement with provision for scaled disagreement or partial credit.," Psychol. Bull., 1968. 